\title{
Ways of economic development of the agroindustrial complex of the South federal district
}

\author{
Liubov Pudeyan ${ }^{1 *}$, and Tatyana Kuchnarenko ${ }^{1}$ \\ ${ }^{1}$ Don State Technical University, pl. Gagarina, 1, Rostov-on-Don, Rostov Region, 344003, Russia
}

\begin{abstract}
The article pays attention to the assessment and development directions of the economic development path of the agro-industrial complex of the Southern Federal District. It was found that the most realistic prospects for the recovery of the domestic economy, with existing opportunities, are largely associated with the active development of import substitution, primarily due to the attraction of FDI. The main task of the Russian Federation is to increase income from the export of agricultural products. This is due to the fact that in the Southern Federal District they produce a large share of agricultural products, in addition, the Kuban and the Rostov Region have exits to the Black and Azov Seas (the main example is the Novorossiysk commercial sea port), all the main flows of cargo go through their ports today. Export shipments are growing annually. The author proposes that in order to strengthen economic security and ensure the sustainable development of the Southern Federal District in the face of economic sanctions, the economic system management bodies require a combination of centralized and decentralized approaches to economic formation, ensuring economic security and improving international competitiveness.
\end{abstract}

\section{Introduction}

The current stage of development of the world economy forms a new agenda in the system of international economic relations, introduces new elements in the relationship between states, their groups and international economic and financial organizations. Globalization, popular at the end of the twentieth century, is beginning to crack, and conflicts of interest are increasingly coming to the fore. A special place among the new challenges facing the agro-industrial complex.

The Southern Federal District is the most important geopolitical, strategic, economic and agrarian region of Russia. The population of the okrug as of 01.01.2021, according to the Federal State Statistics Service, was 16466.1 thousand people. (about 11.2\% of the population of the Russian Federation), of which the share of the rural population was $37.3 \%$ [1]. Favorable natural and climatic conditions in the district contribute to the development of various branches of agriculture. Agricultural producers in the Southern Federal District specialize in the production of such basic types of crop production as cereals, oilseeds,

* Corresponding author: pudeyan.liuba@yandex.ru 
vegetables, and in the products of livestock industries - dairy and beef cattle breeding. Thus, the Southern Federal District is the leader in the production of grain crops in the Russian Federation.

The results of the study of the functioning of various categories of farms and other institutional forms of the agro-industrial complex of the Southern Federal District allow us to determine the current trends in their development, to determine the role of each structure in ensuring the food security of the country and the district. The research carried out during the implementation of national projects, the implementation of which has become a strategic goal of the state's development, is especially relevant. At the same time, there are still problematic issues of their clear definition, the specifics of international economic sanctions in relation to the agro-industrial complex, therefore the topic of the work is relevant.

In the Russian economy today, it remains problematic to overestimate the role of the agro-industrial complex, because the share of this industry in the country's total GDP is approximately $5-6 \%$ [2]. This branch of the economy produces over $70 \%$ of all consumer goods in the country. The agro-industrial complex accounts for $30 \%$ of all employees.

The problems of the functioning of agro-industrial enterprises and their role in the development of the agro-industrial complex have been studied by many leading economists. Among them: A.G. Movsesyan, V.G. Bespakhotny, M.A. Smirnov and other economists. These economists have considered many serious issues, but the study of this issue remains strongly incomplete.

Today, vertically integrated enterprises are faced with a number of serious problems that have not been covered in the framework of existing theoretical models of the behavior of forms [3]. In this regard, it is necessary to develop such recommendations that could increase the efficiency of the activities of agro-industrial enterprises and strengthen their role in the agro-industrial complex of the country [11].

\section{Materials and methods}

The methodological basis of the research in this work was formed by the following methods of scientific knowledge: generalization and comparison, analysis and synthesis, induction and deduction, graphic and tabular interpretation.

The development of agricultural producers is largely influenced by the compliance of production priorities with various conditions. As a result of the analysis of the ratio of various groups of factors affecting agricultural specialization and the results of economic activity of the regions of the Southern Federal District, monitoring of production and, guided by the strategic directions of development of the country's agriculture. Modern problems of the agrarian sector of the economy are closely linked by a chain of sanctions, political and socio-psychological aspects of the development of the agro-industrial complex, although, of course, all these problems are closely related to the key issues of the agrarian economy. Due to the current crisis situation in the functioning of the agrarian economy and social development, the development of socially oriented market relations is hampered.

The main barriers to investment in agriculture in the regions of the Southern Federal District today include:

- introduction of all-Russian economic sanctions;

- unstable, unpredictable and non-transparent state policy;

- insufficient financing of agriculture;

- lack of an efficient and accessible infrastructure for agricultural markets and a marketing system;

- ineffective government policy to support exporters; 
- the vulnerability of the current business model of large agricultural holdings: dependence on changes in the external environment, the need to service debts (external borrowings), etc.

The agricultural sector of the Southern Federal District has significant potential for further growth, however, unresolved systemic imbalances hold back its development [3]. One of the main constraints is the outdated system of land use and land relations, as well as clear and transparent rules of the game in the sector. Agricultural holdings are powerful participants in the agricultural market. Despite certain difficulties caused by internal and external factors, they do not abandon their plans to develop infrastructure and expand their presence in foreign markets.

One of the methods of preventing a crisis in the agro-industrial complex is the entry of the Southern Federal District into world markets with organic products of its own production. The methods by which FDI should be attracted not only for import-substituting activities, but also for the entire economy, include the provision of state assistance to business entities, which may consist in lowering tax rates, subsidies for newly created jobs, and subsidies for personnel training.

Tax incentives can be introduced when an investor implements a project aimed at creating new production facilities in sectors that are priority and engaged in import substitution, new research and development and logistics facilities [4]. Tax incentives for foreign investment in the underdeveloped regions of the country are also possible, since there are no provisions in the current legislation to encourage foreign investment in these territories. Restoring the functioning of free economic zones (FEZ) is a possible way to improve the country's investment climate and attract foreign investment. In order to increase the attractiveness of the FEZ, it is necessary to develop the infrastructure of all spheres, from transport to the infrastructure of the digital economy. To implement the policy of import substitution, it is necessary not only in "defensive" (which includes import substitution), but also in "offensive" (for example, counter-sanctions) strategies, which will allow the economic system to move to the next level of competitive development.

An example of an offensive strategy is the development of the GLONASS system, which is designed to reduce the potential problems associated with the danger of a GPS system shutdown. This tool once again confirms the need for infrastructure development, including in the field of breakthrough innovative technologies. Such technologies include the creation of electronic government, administrative marketing, legalization of the use of cryptocurrency, and so on. Main supplying countries for December 2019 - December 2020 are presented in Table 1.

Table 1. Main supplying countries for December 2019 - December 2020.

\begin{tabular}{|c|c|c|}
\hline Country & Purchase volume & Share \\
\hline China & $\$ 56.4$ billion & $22.2 \%$ \\
\hline Germany & $\$ 26.9$ billion & $10.6 \%$ \\
\hline USA & $\$ 13.3$ billion & $5.2 \%$ \\
\hline Belarus & $\$ 12.7$ billion & $4.4 \%$ \\
\hline Italy & $\$ 11.2$ billion & $3.9 \%$ \\
\hline France & $\$ 9.97$ billion & $3.7 \%$ \\
\hline Japan & $\$ 9.41$ billion & $3.1 \%$ \\
\hline South Korea & $\$ 7.89$ billion & $2.3 \%$ \\
\hline Ukraine & $\$ 5.77$ billion & $2.2 \%$ \\
\hline Kazakhstan & $\$ 5.59$ billion & $2.1 \%$ \\
\hline Poland & $\$ 5.46$ billion & $1.8 \%$ \\
\hline Turkey & $\$ 4.58$ billion & $1.7 \%$ \\
\hline England & $\$ 4.28$ billion & $1.6 \%$ \\
\hline Czech & $\$ 4.01$ billion & $1.5 \%$ \\
\hline Netherlands & $\$ 3.92$ billion \\
\hline
\end{tabular}


Main buying countries for December 2019 - December 2020 are presented in Table 2.

Table 2. Main purchasing countries.

\begin{tabular}{|c|c|c|}
\hline Country & Purchase volume & Share \\
\hline China & $\$ 59.6$ billion & $12.4 \%$ \\
\hline Netherlands & $\$ 47.8$ billion & $9.9 \%$ \\
\hline Germany & $\$ 36.1$ billion & $7.5 \%$ \\
\hline Belarus & $\$ 23$ billion & $4.8 \%$ \\
\hline Turkey & $\$ 22.5$ billion & $4.7 \%$ \\
\hline South Korea & $\$ 19.6$ billion & $4.1 \%$ \\
\hline Italy & $\$ 17.8$ billion & $3.7 \%$ \\
\hline Poland & $\$ 16.7$ billion & $3.5 \%$ \\
\hline Kazakhstan & $\$ 13.6$ billion & $2.8 \%$ \\
\hline USA & $\$ 13.3$ billion & $2.8 \%$ \\
\hline Japan & $\$ 13.3$ billion & $2.8 \%$ \\
\hline Finland & $\$ 11.9$ billion & $2.5 \%$ \\
\hline Ukraine & $\$ 10.2$ billion & $2.1 \%$ \\
\hline England & $\$ 10.1$ billion & $2.1 \%$ \\
\hline Belgium & $\$ 9.84$ billion & $2 \%$ \\
\hline
\end{tabular}

For many product groups, the share of imports has decreased. Thus, compared to 2015 , the share of imports for pork, poultry and cheeses, beef, milk powder has significantly decreased, while the import of these products occupies more than half of all retail commodity resources.

\section{Results and discussion}

One of the ways for the development of the Russian segment of the agro-industrial complex, agriculture of the Southern Federal District may be the creation of specialized agricultural holdings, companies in the agricultural production segment, large taxpayers for the production, processing and sale of milk, as well as dairy and meat products. An agricultural holding is a large-scale agricultural company, a large manufacturer and employer, and, as the largest representatives of the segment and large taxpayers, have a significant impact on the rural areas of the Russian Federation [5]. Agricultural holdings are created in the following stages. The main way to create these structures is to invest capital, both domestic and foreign, first in the processing industry. this provides a faster payback period for agricultural holdings. Then it is necessary to ensure the sale of the manufactured products [6]. In this regard, it is necessary to create logistics departments and our own sales network. The next stage is the creation of our own agricultural production through the lease of land plots and the purchase of resources for the production of products for the buyer. Significant attention among scientists is caused by the organization of the management system of an agricultural holding, a large-sized company in the agricultural segment, a large manufacturer and employer, giants in the agricultural segment, large manufacturers and employers. holdings. The conditions for their formation are the same as the conditions for the creation of other integrated structures.

The main unsolved problems of the agro-industrial complex of the Southern Federal District include: 
1. Creation of agricultural holdings will lead to monopolization of the agricultural market. Every year, the production of products by agricultural holdings is an increasing volume in the share of all agricultural products. In connection with the monopolization of this market, prices for products will rise and business pressure on the authorities will increase.

2. One of the organizations that also considers problems in this industry is the World Bank. This industry is in need of structural transformation in order to increase its exports to other countries and increase the competitiveness of its products.

The following reforms act as structural transformations: updating the technological base, expanding the processing of food production, increasing the added value of products, introducing a more efficient system of labor motivation, as well as increasing the productivity of the product itself. The World Bank believes that Russia has set a high level of prices for domestic products, which is why investments will only go to the primary agricultural production sector, since the payback period in it is shorter than in the processing industry of these products. It is also noted in this report that the improvement of the processing industry for the production of products should contribute to the growth of the entire agro-industrial complex of the Southern Federal District.

3. Disproportion in the development of crop and livestock production. At the beginning of the agrarian reforms, the plant growing industry was affected. Land reform was carried out. Its essence was that the production of agricultural products took place only in zones with favorable climatic conditions. In these regions, the emphasis was placed on the cultivation of agricultural crops such as commercial grain, the production of sugar beets, sunflower seeds. Because of this, there was a reduction in the cultivation of fodder crops necessary to support animal husbandry. As a result, the main problem is that 49 the increased gross crop production did not affect the growth of livestock production.

4. Insufficient development of scientific and technical potential and our own scientific base, it is necessary to create a base for the production of highly qualified personnel capable of gradually improving the quality of products and improving production itself. At the moment, there are 50 agricultural higher educational institutions in Russia, which graduate annually about 25,000 highly qualified specialists who are appreciated not only in the territory of the Russian Federation and are free to take free places for the development of agriculture. Thanks to the introduction of new technologies in the field of agriculture, it will be possible to breed new species of asthenia and animals that will be more resistant to severe climatic conditions and will have high quality.

5. The differentiation of rural areas and cities continues to grow between regions that are in different natural and climatic conditions. In different regions, the conditions are different and in this regard, different results are obtained, and in regions with poor natural and climatic conditions, people from rural areas move to cities. For example, you can compare the Krasnodar Territory, which has excellent conditions, and the Murmansk Region, where the land is not very suitable for crop production.

If we talk about the current situation, there is an interesting paradox. As a rule, the more agrarian a country is developed (these are, first of all, the countries of Western Europe, America, Canada), the greater the role of farmers there. We do not find agricultural holdings there; the agricultural process itself is based on farms. Of course, they are excellently equipped, they are superbly technologically equipped, but business, large agribusiness does not go directly to the sphere of agricultural production, preferring to go to banks, preferring to create trade networks, and so on and so on. According to forecasts of the Ministry of Agriculture, by 2024 the Southern Federal District will increase the export of agricultural products by almost one and a half times: from the current $\$ 8.4$ billion to $\$$ 12.2 billion. The share of the Southern Federal District in the total volume of planned Russian exports will amount to $27.1 \%$, which will allow the Okrug to take a leading 
position in exports in the country. To achieve the export targets, the Southern Federal District must not only develop the transport and logistics infrastructure, but also significantly increase the production of agricultural products by 2024.In particular, it is necessary to increase the gross harvest of grain crops - up to 35.6 million tons, oilseeds - up to 6,7 million tons. It is also necessary to increase the production of livestock and poultry to 1.7 million tons, milk production - up to 4 million tons [7].

\section{Discussion}

By developing the potential of the agricultural sector, Russia will be able to ensure food security and become a leader in the world exporters of agricultural products.

Models that can be proposed based on the results of studying foreign experience, in particular, the experience of the countries of the European Union, may be effective in Russia, provided that a new security ideology is formed, the basis of which is the achievement of sustainable economic development based on the efficient use of resources and compliance with the requirements of legislation and regulatory legal documents. In the end, the successful protection by developed countries of their national economic interests at the present stage of the development of the world economy depends on the stability and level of competitiveness of national economies. Therefore, for Russia today, the most important task of state policy in the field of ensuring economic security should be the modernization of the national economy based on innovative development of the economy with a balanced use of foreign experience in strengthening national economic security.

In the current crisis, the Southern Federal District has optimal opportunities to take advantage of the advantages of a certain stage of globalization. However, the shortcomings of the existing institutional structures against the background of the absence of a long-term strategy for the development of product markets, qualitative changes in the state of infrastructure, insufficient attention to the development of information and communication technologies, and technological renewal of the economy significantly limit the rate and scale of increasing the country's competitiveness and attracting it to the global space. Against the background of a decrease in demand for some types of products that are traditionally exported by the Russian Federation, and the transition to domestic consumption, it is necessary to adjust its positions in global markets.

Let us consider in more detail the factors influencing the international competitiveness of the Southern Federal District.

1. Development of consumer markets. The agricultural market has significant potential to increase productivity and land use. Additional prospects for the Southern Federal District can be opened through the use of new technologies, changes in enterprise structures, product characteristics, supply chains and processing cycles.

2. Food security. One of the proposals aimed at stimulating the internal market is a reform of technical regulation: requirements for product quality should not be recommended, but mandatory (today only safety requirements are mandatory), a systematic approach to organizing a national food quality management system, a national system is required. monitoring, training of highly qualified specialists in this area. The future expansion and simplification of the access of goods of the Southern Federal District to the markets of other countries will be possible subject to the harmonization of the technical regulation system with international requirements and the completion of the reform of the system of state control over food safety and quality.

The market is oversaturated with low-quality products, and unscrupulous business ignores the rights and interests of consumers, using the inaction of the relevant authorities.

The safety of food products and food raw materials of the Southern Federal District is 
interconnected with the social component of the strategy for sustainable development of society in connection with the fact that it is one of the main factors that determine the state of health of the country's population.

In order to increase the competitiveness of goods, as well as to prevent the realization of the risks of worsening the epidemic epizootic situation in the Southern Federal District, the main task of the state policy to ensure food safety should be: organizing effective control over the quality of food entering the market, maintaining the existing national system of food safety and quality based on the implementation of state epidemic and veterinarysanitary control and supervision.

The priorities of state support for the Southern Federal District should also be aimed at stimulating the production of domestic high-quality competitive food products using resource-saving and environmentally friendly technologies.

3. New trade links. It should be noted that an additional, but no less important condition for the successful development of new markets is to improve the quality of the goods offered. In the short term, steps in this direction are associated with high costs, but they are very important for strengthening the country's potential to influence the country's position in world trade markets. These measures are becoming especially in the face of high geopolitical tensions. Economic and demographic growth is characteristic of the rapidly developing markets of Asia, the Middle East and Africa. Therefore, consolidating market positions in these regions is an important task, but its implementation requires the development of a long-term strategy, the implementation of which should rely on new instruments to proactively stimulate trade and to finance exports.

So, one of the key tasks of the economic policy of the Southern Federal District is to increase its competitiveness and create appropriate conditions for this.

4. Strengthening the economic advantages of the agro-industrial complex of the Southern Federal District. Investments in industrial technology upgrades can significantly reduce energy costs and increase productivity, which dictates the need to find coordinated strategic actions.

In the agricultural sector of the Southern Federal District, important measures can be: improvement of transport infrastructure and storage systems, the use of high-quality fertilizers and the consistent introduction of high-tech machinery.

So, the above can be reflected by the mechanism of strengthening economic security and ensuring sustainable development of agriculture in the Southern Federal District in the context of economic sanctions (Fig. 1).

5. The need to attract investment Attraction of direct investment and the development of partnerships with multinational companies will provide an opportunity for technology transfer. So, for example, it is necessary to continue to develop in this direction partnership with Finland, which suffered from the imposition of sanctions against the Russian Federation more than other EU countries.

6. Competition for innovation. In addition to official government institutions, the country lacks a systematic approach to economic modernization that takes into account the specifics of the innovation market. Small and medium-sized enterprises (SMEs) play an important role not only in creating new jobs, but in absorbing innovation and technology. In the Russian Federation, SMEs operate in an extremely difficult environment, which creates significant obstacles for small businesses [12]. 


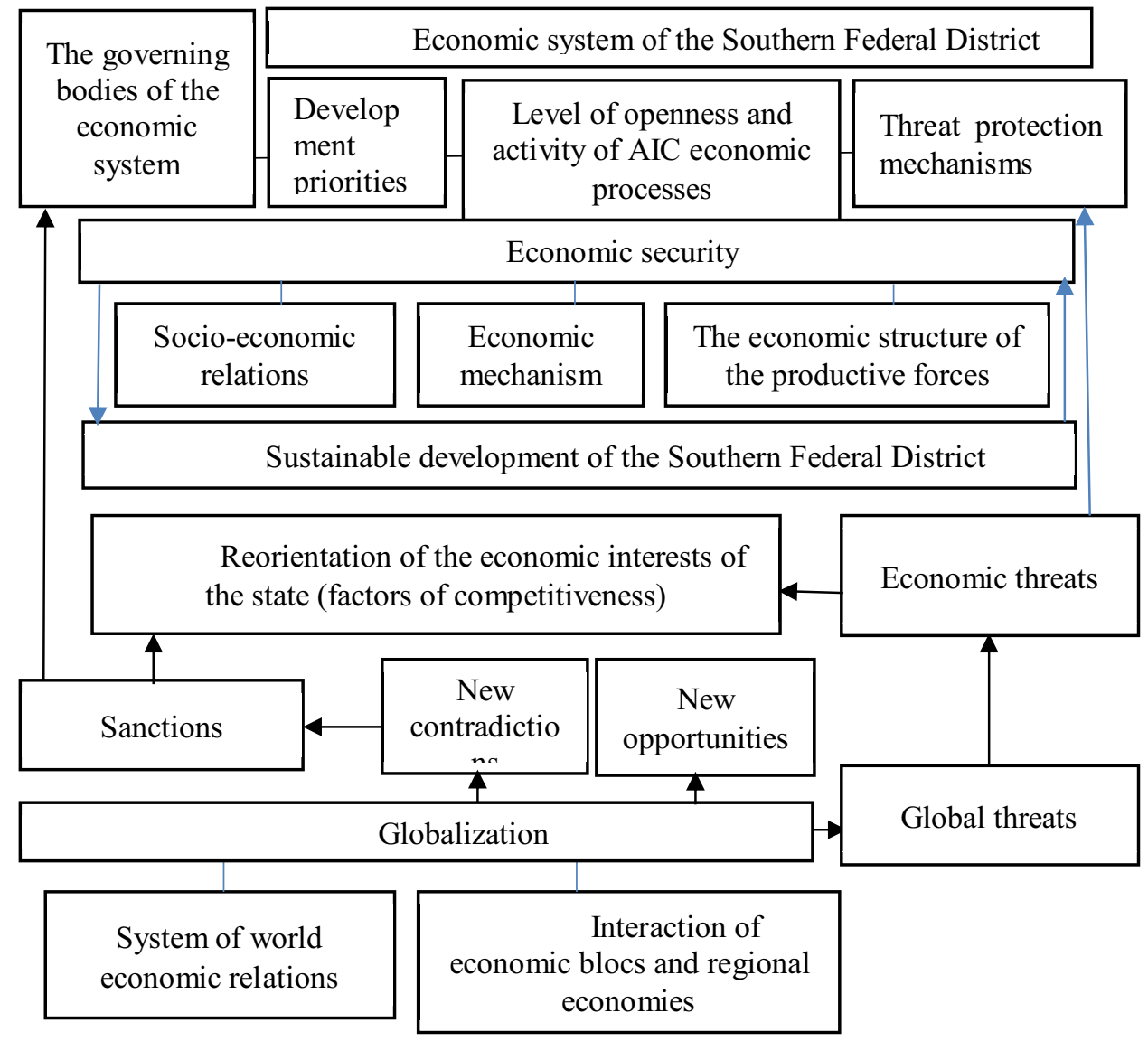

Fig. 1. Mechanism for strengthening economic security and ensuring sustainable development of agriculture in the Southern Federal District.

The task of creating conditions for increasing the efficiency of the economy of the Southern Federal District can be solved only as a result of modernization, which is successfully carried out only if there is an institutional environment that supports it.

7. Improving institutions.

Analysis of the factors of increasing the international competitiveness of the Southern Federal District allows us to make the following observations:

- despite the crisis conditions, a high level of education and training, together with the market capacity, leave the possibility of further development;

- the main problem of the country remains the weak institutional environment and the lack of macroeconomic stability;

- the country practically does not change the level of its infrastructure, does not expand, does not attract new innovations on a large scale.

8. Application of blockchain technologies in public administration.

Today, agro-industrial holdings of the Southern Federal District do not widely use blockchain technologies in the field of public administration, and have not analyzed the advantages and difficulties of their application [4]. The agricultural sector of the Southern Federal District, in particular, for maintaining an animal identification register, which helps to track the path of livestock products from the moment the animal is born until the moment the products are delivered to the retail network.

Thus, to counteract the impact of economic sanctions and increase the competitiveness 
of the economy of the Southern Federal District, it is necessary to develop a state competitive strategy that will be aimed at enhancing external and internal conditions for the realization of the interests of the state, society and the population.

\section{Conclusion}

An analysis of the country's agricultural sector made it possible to conclude that the basis of food security in the Russian Federation is a stable domestic production of agricultural products and food [13]. Implementation of an active state policy aimed at creating an effective agro-industrial complex, improving the level and quality of life of the rural population. Since in countries with market economies there is a fairly large positive experience in matters of national economic security, at present, foreign experience in regulating economic security is of interest.

The emerging threats to the economy of the Southern Federal District made it necessary to search for new ways to increase competitiveness and increase the production of agricultural products and food. Thus, the region faced the task of increasing the level of food security, one of the most important components of economic security. Foreign experience in improving food security illustrates the need for a certain level of budgetary, financial and production support. It is necessary to strengthen the investment and innovative development of the agricultural industry and the agricultural sector of the Southern Federal District; take measures aimed at improving the mechanism of financial recovery of agricultural producers. Improving the standard of living of the rural population, employment, development of rural areas is also one of the directions for ensuring the food security of the country.

The goal of the economic security of the Southern Federal District should be the sustainable development of the economic system, which is achieved through the influence of the governing bodies of the economic system, as well as by optimizing the level of openness and activity of economic processes.

The slowdown in economic growth in the country, the policy of sanctions confrontations between Russia and Western countries, the impact of the looming next world economic crisis associated with the spread of coronavirus infection (COVID-19), which limited the allocation of state financial resources to support the industry, do not allow solving the systemic problems of agricultural production: financial stability and debt burden of agricultural producers; technical and technological modernization of the industry; competitiveness of products in the domestic and foreign markets. To strengthen economic security and ensure sustainable development of the Southern Federal District in the context of economic sanctions, the authorities of the economic system require a combination of centralized and decentralized approaches to the formation of the economy, ensuring economic security and increasing the level of international competitiveness. Such factors can be: the development of consumer markets, food security, new trade ties, strengthening economic advantages, attracting investment, competition for innovation, improving institutions, the use of blockchain technologies in public administration. By fully or at least partially realizing its agrarian potential, the Southern Federal District will be able to ensure national food security and become one of the leaders in the world export of agricultural products, raw materials and foodstuffs, and thereby strengthen its position in the Russian and world food markets. 


\section{References}

1 E. Bornhofen, T. Ramires, T. Bergonci, et al., Agricultural Systems, 173, 281-288 (2019)

2 S. K. Volkov, Regional and Sectoral Economic Studies, 15-20, 137-144 (2015), [An electronic resource]. Access mode: http:// www.usc.es/economet/journals2/eers/eers15210.pdf, free.

3 A. V. Mikhailova, T. K. Medvedskaya, S. V. Laptev, et al., Academy of Entrepreneurship Journal, 25(2), 1-6 (2019)

4 V. Tkach, E. Medyukha, N. Zemlyakova, et al., in Proceedings of 12th International Scientific Conference on Agricultural Machinery Industry, INTERAGROMASH 2019, 012134 (2019)

5 E. V. Dorzhieva, E. L. Dugina, International Journal of Economics and Financial Issues, 5, 238-247 (2015)

6 M. V. Kazakovtseva, F. Z. Gumarova, E. I. Tsaregorodtsev, Mediterranean Journal of Social Sciences, 6(3), 213-220 (2015)

7 C. Perez, Techno-Economic Paradigms (Anthem Press, The Other Canon Foundation, London, 2011)

8 M. V. Gestrin, J. Staudt, The digital economy, multinational enterprises and international investment policy (Paris, 2018), URL: http://www.oecd.org/investment/investment-policy/The-digital-economymultinational-enterprises-and-international-investment-policy.pdf

9 A. V. Shokhnekh, N. N. Skiter, A. F. Rogachev, et al., Journal of Advanced Research in Law and Economics, 7(7), 1854-1857 (2016)

10 L. G. Matveeva, A. Y. Nikitaeva, and O. A. Chernova Terra Economicus, 16(1), 134145 (2018)

11 N. A. Kosolapova, L. G. Matveeva, A. Y. Nikitaeva, et al., Journal of Hydrology, 553, 438-446 (2017)

12 T. Kuchnarenko, L. Pudeiyan, Mechanisms for the modernization of regions having agricultural specialization in the imperatives of the digital economy, in Proceedings of XIII International Scientific and Practical Conference «State and Prospects for the Development of Agribusiness - INTERAGROMASH 2020», 29 June 2020 (2020)

13 T. Kushnarenko, P. Shumilin, O. Yuryeva, et al., Accounting management model of agribusiness: Engineering tools for accounting and analysis, in Proceedings of 2020 Topical Problems of Green Architecture, Civil and Environmental Engineering 2019 (TPACEE 2019), 05 May 2020 (2020)

14 V. Mau, The Russian economy in 2017. Trends of Perspective (Publishing house of the Gaidar Institute, Moscow, 2018)

15 V. G. Zakshevsky, O. G. Charykova, I. N. Merenkova, IOP Conference Series: Earth and Environmental Science, 012007 (2019)

16 E. Bornhofen, T. Ramires, T. Bergonci, L. Nakamura, A. Righto, Agricultural Systems, 173, 281-288 (2019) 